\title{
RATIO DECIDENDI MAHKAMAH AGUNG DALAM PUTUSAN NOMOR 50 P/HUM/2018
}

\author{
Goentur Akhmad Febrianto \\ Program Studi Magister Kenotariatan, Universitas Surabaya \\ e-mail: gunturfebri28@gmail.com
}

\begin{abstract}
ABSTRAK
Pasca Putusan Mahkamah Agung Nomor 50 P/HUM/2018, Ujian Pengangkatan Notaris dihapus sebagai syarat untuk dapat diangkat menjadi notaris. Pengangkatan dan pemberhentian notaris tidak perlu menjadi kewenangan organisasi notaris sebab pada hakikatnya salah satu karakteristik notaris sebagai pejabat umum adalah diangkat dan diberhentikan oleh pemerintah. Tidak tepat apabila kewenangan tersebut dilimpahkan kepada organisasi notaris yang notabene bukan organ pemerintah karena akan menghilangkan karakteristik yang melekat pada notaris sebagai pejabat umum. Kewenangan untuk mengangkat dan memberhentikan notaris adalah kewenangan Menteri Hukum dan Hak Asasi Manusia, sedangkan organisasi notaris sendiri dibentuk dengan tujuan untuk meningkatkan kualitas profesi notaris melalui kegiatan pendidikan dan pelatihan, pertemuan ilmiah, ceramah, seminar, dan sebagainya.
\end{abstract}

Kata Kunci: putusan Mahkamah Agung; pengangkatan notaris; organisasi notaris

\begin{abstract}
Post Supreme Court verdict Number 50 P/HUM/2018, Notary Assignment Exam removed as one of the requirements to be assigned a notary. The assignment and dismissal of the notary public does not need to be Notary Public Organization authority for the fact that one of the characteristics of the notary public is assigned and dismissed by the government. Less precise when the authority delegated to the Notary Public Organization which is not an organ of the government because it will eliminate the characteristics inherent in a notary public. The authority to assign and dismiss notary public is in the hands of the Minister of Laws and Human Rights. While the presence of Notary Public Organization in general only aims to improve the quality of the profession of notary public through educational activities and training, scientific meetings, lectures, seminars, and so on.
\end{abstract}

Keywords: supreme court verdict; assignment of notary public; notary public organization

\section{PENDAHULUAN}

Pada tanggal 20 September 2018, Mahkamah Agung mengeluarkan Putusan No. 50 P/HUM/2018, yang dalam amar putusannya memutuskan antara lain sebagai berikut:

1. Menyatakan Pasal 2 ayat (2) huruf j Peraturan Menteri Hukum dan Hak Asasi Manusia No. 62 Tahun 2016 tentang Perubahan Atas Peraturan Menteri Hukum dan Hak Asasi Manusia No. 25 Tahun 2014 tentang Syarat dan Tata Cara Pengangkatan, Perpindahan, Pemberhentian dan Perpanjangan Masa Jabatan Notaris dan Peraturan Menteri Hukum dan Hak Asasi
Manusia No. 25 Tahun 2017 tentang Ujian Pengangkatan Notaris, bertentangan dengan peraturan perundang-undangan yang lebih tinggi yakni Undang-Undang No. 2 Tahun 2014 tentang Perubahan Atas Undang-Undang No. 30 Tahun 2004 tentang Jabatan Notaris;

2. Menyatakan Pasal 2 ayat (2) huruf j Peraturan Menteri Hukum dan Hak Asasi Manusia No. 62 Tahun 2016 tentang Perubahan Atas Peraturan Menteri Hukum dan Hak Asasi Manusia No. 25 Tahun 2014 tentang Syarat dan Tata Cara Pengangkatan, Perpindahan, Pemberhentian dan 
Perpanjangan Masa Jabatan Notaris dan Peraturan Menteri Hukum dan Hak Asasi Manusia No. 25 Tahun 2017 tentang Ujian Pengangkatan Notaris, tidak mempunyai kekuatan hukum mengikat dan tidak berlaku umum.

Para pemohon yang mengajukan permohonan uji materiil tersebut terdiri atas pengelola dan pengajar Magister Kenotariatan Universitas Jambi maupun Calon Notaris dan atau Anggota Luar Biasa Ikatan Notaris Indonesia mendalilkan bahwa ketentuan Pasal 2 ayat (2) huruf j Permenkumham No. 62 Tahun 2016 bertentangan dengan Pasal 3 Undang-Undang No. 2 Tahun 2014. Demikian juga halnya dengan Permenkumham No. 25 Tahun 2017. Sehingga kedua Peraturan Menteri tersebut harus dicabut dan dinyatakan tidak memiliki kekuatan hukum mengikat dan tidak berlaku umum.

Dalam pertimbangan hukumnya, MA berpendapat bahwa syarat pengangkatan notaris dalam ketentuan Pasal 3 UU No. 2 Tahun 2014 bersifat limitatif, yang berarti syarat yang harus dipenuhi oleh calon notaris hanya yang ditentukan oleh ketentuan tersebut. Sedangkan syarat tambahan berupa kelengkapan dokumen sebagaimana tercantum dalam Penjelasan Atas UU No. 2 Tahun 2014 dan Permenkumham No. 62 Tahun 2016 harus sejalan dengan maksud (intent) pembentuk undang-undang secara keseluruhan serta tidak boleh bertentangan dengan materi muatan Pasal 3 UU No. 2 Tahun 2014.

MA berpendapat bahwa kelengkapan dokumen berupa fotokopi tanda kelulusan Ujian Pengangkatan Notaris yang diselenggarakan oleh Direktorat Jenderal Administrasi Hukum Umum sebagaimana diatur dalam ketentuan Pasal 2 ayat (2) huruf j Permenkumham No. 62 Tahun 2016 telah memperluas norma yang terkandung dalam Pasal 3 UU No. 2 Tahun 2014 karena hal tersebut tidak pernah diperintahkan oleh UU No. 2 Tahun 2014.

MA juga berpendapat bahwa penyelenggaraan ujian pengangkatan notaris oleh Direktorat Jenderal Administrasi Hukum Umum tidak tepat karena hal tersebut merupakan campur tangan pemerintah dalam menentukan kelayakan calon notaris. Menurut MA, pengangkatan notaris seharusnya dilakukan oleh Organisasi Notaris untuk menjamin independensi dan kemandirian dalam melaksanakan tugasnya. Organisasi Notaris yang dimaksud ialah Ikatan Notaris Indonesia (selanjutnya disebut INI), yang merupakan satu-satunya wadah profesi notaris yang bebas dan mandiri yang dibentuk dengan maksud dan tujuan untuk meningkatkan kualitas profesi notaris.

Namun menurut Pasal 2 UU No. 30 Tahun 2004, Notaris diangkat dan diberhentikan oleh menteri, yang berarti bahwa pengangkatan dan pemberhentian notaris merupakan kewenangan menteri, bukan Organisasi Notaris. Menteri yang dimaksud adalah Menteri yang menyelenggarakan urusan pemerintahan di bidang hukum, yakni Menteri Hukum dan Hak Asasi Manusia.

Dibatalkannya ketentuan Pasal 2 ayat (2) huruf j Permenkumham No. 62 Tahun 2016 dan Permenkumham No. 25 Tahun 2017 oleh MA memberikan jaminan kepastian hukum mengenai pengangkatan notaris dan perlindungan hukum bagi calon notaris. Dengan adanya putusan tersebut, penulis hendak menganalisis ratio decidendi MA dan apakah pengangkatan dan pemberhentian notaris menjadi kewenangan Organisasi Notaris dalam suatu penelitian berjudul "Ratio Decidendi Mahkamah Agung dalam Putusan Nomor 50 P/HUM/2018”.

\section{PERUMUSAN MASALAH}

Berdasarkan pendahuluan di atas, ada dua isu hukum yang dibahas dalam penelitian ini, yaitu ratio decidendi MA membatalkan ketentuan Pasal 2 ayat (2) Hurufj Permenkumham No. 62 Tahun 2016 dan Permenkumham No. 25 Tahun 2017 serta perlukah pengangkatan dan pemberhentian notaris menjadi kewenangan organisasi notaris.

\section{METODE PENELITIAN}

Penelitian ini merupakan penelitian hukum normatif. Penelitian hukum adalah suatu proses untuk menemukan aturan hukum, prinsip-prinsip hukum, maupun doktrin-doktrin hukum guna menjawab isu hukum yang dihadapi. ${ }^{1}$ Ada dua pendekatan yang digunakan dalam penelitian ini, yakni pendekatan perundang-undangan dan pendekatan konseptual.

\section{PEMBAHASAN}

\section{Pengangkatan Notaris Menurut UU No. 2 Tahun 2014}

Kehadiran jabatan notaris dikehendaki oleh hukum dengan maksud untuk membantu dan melayani

\footnotetext{
${ }^{1}$ Peter Mahmud Marzuki. (2011). Penelitian Hukum. Jakarta: Kencana, h. 35.
} 
masyarakat yang membutuhkan bukti tertulis berupa akta autentik mengenai perbuatan, perjanjian, dan penetapan yang diharuskan oleh peraturan perundang-undangan atau yang dikehendaki oleh yang berkepentingan untuk dituangkan dalam akta autentik. Karena lahir dari kebutuhan masyarakat, notaris harus mempunyai semangat melayani.

UU No. 2 Tahun 2014 menentukan bahwa notaris memiliki kewenangan untuk membuat akta autentik mengenai semua perbuatan, perjanjian, dan penetapan yang diharuskan oleh peraturan perundang-undangan dan/atau yang dikehendaki oleh yang berkepentingan untuk dinyatakan dalam akta autentik, menjamin kepastian tanggal pembuatan akta, menyimpan akta, memberikan grosse, salinan dan kutipan akta, semuanya sepanjang pembuatan akta itu tidak juga ditugaskan atau dikecualikan kepada pejabat lain atau orang lain yang ditetapkan oleh undang-undang.

Sebagai suatu jabatan publik, jabatan notaris mempunyai karakteristik sebagai berikut:

1. Sebagai jabatan. Jabatan notaris ialah lembaga yang diciptakan oleh negara. Jabatan notaris dibuat oleh hukum untuk memenuhi fungsi tertentu serta bersifat berkesinambungan.

2. Mempunyai kewenangan tertentu. Agar dapat berjalan baik dan tidak berbenturan dengan wewenang jabatan lain, setiap wewenang harus diberikan berdasarkan hukum.

3. Diangkat dan diberhentikan oleh pemerintah. Meski diangkat dan diberhentikan oleh pemerintah, hal ini tidak berarti bahwa notaris adalah bawahan (subordinat) pemerintah. Dalam menjalankan jabatannya notaris harus bersifat mandiri, tidak memihak, dan tidak bergantung kepada siapa pun.

4. Tidak menerima gaji atau pensiun. Notaris tidak menerima gaji atau pensiun dari pemerintah, tetapi honorarium dari masyarakat yang menggunakan jasanya.

5. Akuntabilitas kepada masyarakat. Notaris mempunyai tanggung jawab melayani masyarakat. $^{2}$

Secara garis besar, Pasal 3 UU No. 2 Tahun 2014 mengatur delapan syarat utama yang harus dipenuhi agar dapat diangkat menjadi notaris. Kedelapan

\footnotetext{
${ }^{2}$ Habib Adjie. (2009). Hukum Notaris Indonesia (Tafsir Tematik Terhadap UU No. 30 Tahun 2004 tentang Jabatan Notaris). Bandung: Refika Aditama, h. 15-16.
}

syarat tersebut bersifat kumulatif. Artinya apabila salah satu tidak dipenuhi, maka yang bersangkutan tidak dapat diangkat sebagai notaris. Syarat tersebut antara lain mampu secara jasmani dan rohani untuk melaksanakan wewenang dan kewajiban sebagai notaris, menjalani magang atau nyata-nyata telah bekerja sebagai karyawan notaris selama dua tahun berturut-turut atas prakarsa sendiri atau atas rekomendasi organisasi notaris. Calon notaris dapat memilih sendiri kantor yang diinginkan dengan tetap mendapatkan rekomendasi dari organisasi notaris. Hal tersebut dibuktikan dengan surat keterangan tanggal kali pertama magang/bekerja di kantor notaris. Tidak merangkap Pegawai Negeri dan Pejabat Negara sebagaimana dimaksud dalam UU No. 43 Tahun 1999 tentang Perubahan atas UU No. 8 Tahun 1974 tentang Pokok-Pokok Kepegawaian. Tidak merangkap Advokat sebagaimana dimaksud dalam UU No. 18 Tahun 2003 tentang Advokat.

\section{Ratio Decidendi MA Membatalkan Ketentuan Pasal 2 ayat (2) Huruf j Permenkumham No. 62 Tahun 2016 dan Permenkumham No. 25 Tahun 2017}

Pada tanggal 20 September 2018, MA mengeluarkan Putusan No. 50 P/HUM/2018, yang dalam amar putusannya memutuskan antara lain sebagai berikut:

1. Menyatakan Pasal 2 ayat (2) huruf j Permenkumham No. 62 Tahun 2016 tentang Perubahan Atas Permenkumham No. 25 Tahun 2014 tentang Syarat dan Tata Cara Pengangkatan, Perpindahan, Pemberhentian dan Perpanjangan Masa Jabatan Notaris, dan Permenkumham No. 25 Tahun 2017 tentang Ujian Pengangkatan Notaris, bertentangan dengan peraturan perundang-undangan yang lebih tinggi yakni UU No. 2 Tahun 2014 tentang Perubahan atas UU No. 30 Tahun 2004 tentang Jabatan Notaris;

2. Menyatakan Pasal 2 ayat (2) huruf j Permenkumham No. 62 Tahun 2016 tentang Perubahan Atas Permenkumham No. 25 Tahun 2014 tentang Syarat dan Tata Cara Pengangkatan, Perpindahan, Pemberhentian dan Perpanjangan Masa Jabatan Notaris, dan Permenkumham No. 25 Tahun 2017 tentang Ujian Pengangkatan Notaris, tidak mempunyai kekuatan hukum mengikat dan tidak berlaku umum; 
Dalam pertimbangan hukumnya, MA menyatakan bahwa syarat pengangkatan notaris dalam ketentuan Pasal 3 UU No. 2 Tahun 2014 bersifat limitatif, yang berarti syarat yang harus dipenuhi oleh calon notaris hanya yang ditentukan oleh ketentuan tersebut. Sedangkan syarat tambahan berupa kelengkapan dokumen sebagaimana tercantum dalam Permenkumham No. 62 Tahun 2016 harus sejalan dengan maksud (intent) pembentuk undangundang maupun konteks materi secara keseluruhan (sistematis-kontekstual) dan tidak boleh bertentangan dengan materi muatan Pasal 3 UU No. 2 Tahun 2014.

MA juga menyatakan bahwa kelengkapan dokumen berupa fotokopi tanda kelulusan Ujian Pengangkatan Notaris yang diselenggarakan oleh Direktorat Jenderal Administrasi Hukum Umum sebagaimana diatur dalam ketentuan Pasal 2 ayat (2) huruf j Permenkumham No. 62 Tahun 2016 telah memperluas norma yang terkandung dalam Pasal 3 UU No. 2 Tahun 2014 karena hal tersebut tidak pernah diperintahkan oleh UU No. 2 Tahun 2014.

Menurut MA, karena materi muatan Permenkumham No. 25 Tahun 2017 mengatur sesuatu yang tidak diperintahkan oleh undang-undang, maka dengan sendirinya peraturan menteri tersebut secara keseluruhan menjadi batal demi hukum dan tidak mempunyai kekuatan hukum yang mengikat umum.

MA juga menyatakan bahwa penyelenggaraan ujian pengangkatan notaris oleh Direktorat Jenderal Administrasi Hukum Umum tidak tepat karena hal tersebut merupakan bentuk campur tangan pemerintah dalam menentukan kelayakan calon notaris. Menurut MA, pengangkatan notaris seharusnya dilakukan oleh Organisasi Notaris untuk menjamin independensi dan kemandirian dalam melaksanakan tugasnya. Organisasi Notaris yang dimaksud ialah INI, yang merupakan satu-satunya wadah profesi notaris yang memiliki independensi dan kemandirian dalam menyusun kode etik, mengawasi, memberhentikan notaris, termasuk juga menyelenggarakan ujian pengangkatan untuk menentukan kelayakan calon notaris. Hal tersebut menurut Mahkamah Agung tidak dapat tercapai apabila pemerintah turut campur dalam urusan ujian pengangkatan notaris.

Menurut penulis, Putusan MA No. $50 \mathrm{P} /$ HUM/2018 lebih menjamin kepastian hukum dan memberikan perlindungan hukum bagi calon notaris sebab syarat utama yang harus dipenuhi oleh calon notaris sebagaimana diatur dalam ketentuan Pasal 3 UU No. 2 Tahun 2014 memang hanya ada delapan syarat. UU No. 30 Tahun 2004 memang memberikan delegasi kewenangan kepada Menteri untuk mengatur lebih lanjut mengenai syarat dan tata cara pengangkatan notaris, tetapi hal tersebut harus sejalan dengan maksud pembentuk undangundang dan konteks materi undang-undang secara keseluruhan (sistematis-kontekstual). Syarat berupa kelengkapan dokumen sebagaimana diatur dalam ketentuan Pasal 2 ayat (2) Permenkumham No. 62 Tahun 2016 hanya bersifat teknis administratif dan tidak boleh memperluas norma yang terkandung dalam UU No. 2 Tahun 2014. Pemerintah dalam hal ini Menteri Hukum dan Hak Asasi Manusia telah mengeluarkan Peraturan Menteri yang bertentangan dengan undang-undang sehingga justru menimbulkan ketidakpastian hukum mengenai pengangkatan notaris.

Pelaksanaan Ujian Pengangkatan Notaris oleh Direktorat Jenderal Administrasi Hukum Umum sebagaimana diatur oleh Permenkumham No. 25 Tahun 2017 merupakan bentuk campur tangan pemerintah dalam menentukan kelulusan calon notaris. Peraturan Menteri tersebut juga mengatur sesuatu yang tidak pernah diperintahkan oleh UU No. 2 Tahun 2014, sehingga dengan sendirinya materi muatan dalam ayat, pasal, dan/atau bagian Permenkumham No. 25 Tahun 2017 menjadi batal demi hukum dan tidak mempunyai kekuatan hukum yang mengikat umum.

Uji materiil yang dilakukan oleh MA merupakan bentuk perlindungan hukum akibat dikeluarkannya suatu peraturan perundang-undangan. Putusan MA tersebut telah menyatakan bahwa ketentuan Pasal 2 ayat (2) huruf j Permenkumham No. 62 Tahun 2016 dan Permenkumham No. 25 Tahun 2017 bertentangan dengan peraturan perundang-undangan yang lebih tinggi, yakni Undang-Undang No. 2 Tahun 2014 sehingga tidak mempunyai kekuatan hukum mengikat dan tidak berlaku umum.

\section{Pengangkatan Notaris Pasca Putusan MA No. 50 P/HUM/2018}

Pasca Putusan MA No. 50 P/HUM/2018, Permenkumham Nomor 62 Tahun 2016 masih berlaku sebab yang dicabut hanya ketentuan Pasal 2 ayat (2) huruf j. Pengangkatan notaris tidak 
memerlukan Ujian Pengangkatan Notaris sebagai syarat untuk dapat diangkat menjadi notaris. Notaris dapat mengajukan permohonan pengangkatan kepada menteri setelah memenuhi delapan syarat utama dan kelengkapan dokumen pendukung sebagaimana diatur dalam ketentuan Pasal 3 UU No. 2 Tahun 2014 jo. Pasal 2 ayat (1) dan ayat (2) Permenkumham No. 62 Tahun 2016.

Secara ringkas, alur pengangkatan notaris pasca Putusan Mahkamah Agung No. 50 P/HUM//2018 adalah sebagai berikut: 1. Lulus strata dua Kenotariatan (Magister Kenotariatan); 2. Mendaftar sebagai Anggota Luar Biasa (ALB), lulus ujian pendaftaran ALB; 3. Magang selama dua tahun di kantor notaris kemudian dilanjutkan dengan magang bersama yang diadakan oleh pengurus wilayah; 4 . Mengumpulkan delapan belas poin dengan mengikuti kegiatan yang diadakan oleh pengurus pusat, pengurus wilayah, atau pengurus daerah Organisasi Notaris; 5. Lulus ujian Kode Etik Notaris (UKEN); 6. Mengajukan permohonan pengangkatan notaris kepada Menteri Hukum dan Hak Asasi Manusia; 7. Diterbitkannya surat keputusan (SK) pengangkatan notaris oleh Menteri Hukum dan Hak Asasi Manusia; dan 8. Pengambilan sumpah/jabatan notaris.

\section{Kedudukan dan Kewenangan Organisasi Notaris}

Pengertian "organisasi" menurut Kamus Besar Bahasa Indonesia ialah "kesatuan (susunan dan sebagainya) yang terdiri atas bagian-bagian (orang dan sebagainya) dalam perkumpulan dan sebagainya untuk tujuan tertentu". Sementara pengertian "organisasi profesi" ialah "organisasi yang anggotanya adalah orang-orang yang mempunyai profesi yang sama."

Pasal 1 angka 5 UU No. 2 Tahun 2014 menyatakan sebagai berikut "Organisasi Notaris adalah organisasi profesi jabatan notaris yang berbentuk perkumpulan berbadan hukum".

Habib Adjie mengatakan bahwa parameter atau ukuran Organisasi Notaris menurut ketentuan pasal tersebut di atas ada dua hal, yakni berbentuk perkumpulan dan berbadan hukum. Ciri-ciri perkumpulan berbadan hukum adalah sebagai berikut: 1 . Mendapat pengesahan sebagai badan hukum dari instansi berwenang; 2. Mempunyai harta kekayaan terpisah; 3. Mempunyai tujuan tertentu dan kepentingan sendiri; dan 4. Ada organisasi yang teratur.

Kriteria organisasi notaris adalah mempunyai Anggaran Dasar, Anggaran Rumah Tangga, Kode Etik, dan Buku Daftar Anggota. Organisasi Notaris juga perlu menjalankan roda organisasi secara berkesinambungan, seperti mengadakan pertemuan antaranggota sesuai dengan Anggaran Dasar dan Anggaran Rumah Tangga, serta menyelenggarakan pertemuan ilmiah (misalnya seminar, pendidikan dan pelatihan) dan pembinaan bagi para anggotanya. ${ }^{3}$

INI berdiri sejak tanggal 1 Juli 1908 dan diakui sebagai Badan Hukum (rechtspersoon) berdasarkan Penetapan Pemerintah (gouvernements besluit) tanggal 5 September 1908. INI merupakan satusatunya wadah pemersatu bagi semua dan setiap orang yang memangku dan menjalankan tugas jabatan notaris di Indonesia. Pemerintah telah mengakui dan mengesahkan INI sebagai badan hukum dengan Penetapan Menteri Kehakiman tanggal 4 Desember 1958 No. J.A.5/117/6 yang diumumkan dalam Berita Negara Republik Indonesia tanggal 6 Maret 1959 Nomor 19, Tambahan Berita Negara Republik Indonesia Nomor 6. Perubahan anggaran dasarnya yang terakhir telah mendapat persetujuan dari Menteri Hukum dan Hak Asasi Manusia Republik Indonesia berdasarkan Surat Keputusan tanggal 12 Januari 2009 No. AHU-03.AH.01.07 Tahun 2009.

Tujuan INI ialah tegaknya kebenaran dan keadilan serta terpeliharanya keluhuran martabat jabatan Notaris sebagai pejabat umum yang bermutu dalam rangka pengabdiannya kepada Tuhan Yang Maha Esa, Bangsa dan Negara agar terwujudnya kepastian hukum dan terbinanya persatuan dan kesatuan serta kesejahteraan anggotanya. Untuk mencapai tujuan tersebut, INI berusaha:

1) Melakukan kegiatan untuk menumbuhkan kesadaran rasa turut memiliki Perkumpulan yang bertanggung jawab, guna terciptanya rasa kebersamaan di antara sesama anggota dalam rangka meningkatkan peranan, manfaat, fungsi dan mutu Perkumpulan;

2) Melakukan kegiatan untuk meningkatkan mutu dan kemampuan anggota di dalam menjalankan jabatan dan profesinya secara profesional, guna menjaga dan mempertahankan keluhuran martabat jabatan Notaris; 
3) Menjunjung tinggi serta menjaga kehormatan profesi jabatan Notaris, meningkatkan fungsi dan perannya serta meningkatkan mutu ilmu kenotariatan dengan jalan menyelenggarakan pertemuan ilmiah, ceramah, seminar dan sejenisnya serta penerbitan tulisan karya ilmiah;

4) Memperjuangkan dan memelihara kepentingan, keberadaan, peranan, fungsi dan kedudukan lembaga Notaris di Indonesia sesuai dengan harkat dan martabat profesi jabatan Notaris;

5) Mengadakan, memupuk serta membina dan meningkatkan kerja-sama dengan badan, lembaga dan organisasi lain, baik di dalam maupun dari luar negeri yang mempunyai tujuan yang sama atau hampir sama dengan Perkumpulan termasuk dengan lembaga pendidikan atau instansi yang terkait dan yang mempunyai hubungan dengan lembaga kenotariatan;

6) Mengadakan dan menyelenggarakan pendidikan dan pelatihan Notaris, baik dilakukan sendiri maupun bekerjasama dengan pihak lain, serta aktif dalam mempersiapkan lahirnya calon Notaris yang profesional, berdedikasi tinggi, berbudi luhur, berwawasan, dan berilmu pengetahuan luas dan memiliki integritas moral serta memiliki akhlak yang baik;

7) Melakukan usaha lain sepanjang tidak bertentangan dengan asas, pedoman dan tujuan Perkumpulan.

INI juga mempunyai fungsi menetapkan dan menegakkan kode etik. Pengertian kode etik notaris ialah kaidah moral yang ditentukan oleh INI berdasarkan keputusan kongres perkumpulan dan/ atau diatur oleh peraturan perundang-undangan yang berlaku bagi serta wajib ditaati oleh setiap dan semua anggota perkumpulan dan semua orang yang menjalankan jabatan notaris termasuk pejabat sementara notaris dan notaris pengganti.

\section{Perlukah Pengangkatan dan Pemberhentian Notaris Menjadi Kewenangan Organisasi Notaris}

Kewenangan pengangkatan dan pemberhentian notaris termasuk kewenangan atribusi yang diberikan oleh UU No. 30 Tahun 2004 jo. UU No. 2 Tahun 2014 kepada Menteri yang menyelenggarakan urusan pemerintahan di bidang hukum, yakni Menteri Hukum dan Hak Asasi Manusia.
Di negara-negara Asia Tenggara seperti Brunei Darussalam, Kamboja, Malaysia, dan Myanmar notaris bahkan diangkat oleh Raja, Jaksa Agung (Attorney General), atau Mahkamah Agung (Supreme Court). Di Indonesia setelah tahun 1954, pengangkatan notaris dilakukan oleh Menteri Kehakiman yang sebelumnya dilakukan oleh Kepala Negara (Gubernur Jenderal). Hal tersebut dilakukan agar dalam menjalankan tugasnya notaris terbebas dari pengaruh badan eksekutif. Semasa pemerintahan Hindia Belanda pernah ada rencana untuk mendelegasikan pengangkatan para pejabat pada berbagai bidang pemerintahan kepada para direktur pemerintahan umum, tetapi batal karena hak untuk mengangkat adalah suatu hak publik yang bukan merupakan hak-hak perdata sehingga tidak dapat didelegasikan, dan pelaksanaannya merupakan suatu kewajiban.

Penulis berpendapat bahwa pengangkatan dan pemberhentian notaris tidak perlu menjadi kewenangan Organisasi Notaris sebab pada hakikatnya salah satu karakteristik notaris sebagai pejabat umum ialah diangkat dan diberhentikan oleh pemerintah. Tidak tepat apabila kewenangan tersebut dilimpahkan kepada Organisasi Notaris yang notabene bukan organ pemerintah, melainkan hanya perkumpulan berbadan hukum, karena akan menghilangkan karakteristik yang melekat pada notaris sebagai pejabat umum. Sesuai dengan ketentuan Pasal 2 UU No. 30 Tahun 2004, kewenangan untuk mengangkat dan memberhentikan notaris berada di tangan pemerintah, dalam hal ini Menteri Hukum dan Hak Asasi Manusia. Sedangkan keberadaan Organisasi Notaris secara umum hanya bertujuan untuk meningkatkan kualitas profesi notaris melalui kegiatan pendidikan dan pelatihan, pertemuan ilmiah, ceramah, seminar, dan sebagainya, baik di tingkat pusat, wilayah, maupun daerah.

\section{PENUTUP \\ Kesimpulan}

Pasca Putusan MA No. 50 P/HUM/2018, Permenkumham No. 62 Tahun 2016 masih berlaku sebab yang dicabut hanya ketentuan Pasal 2 ayat (2) huruf j. Ratio Decidendi MA membatalkan ketentuan Pasal 2 ayat (2) huruf j Permenkumham No. 62 Tahun 2016 dan Permenkumham No. 25 Tahun 2017 adalah Pasal 2 ayat (2) huruf j Permenkumham No. 62 
Tahun 2016 tidak sejalan dengan maksud pembentuk undang-undang dan telah memperluas norma yang terkandung dalam Pasal 3 UU No. 2 Tahun 2014, sedangkan Permenkumham No. 25 Tahun 2017 mengatur sesuatu yang tidak pernah diperintahkan oleh UU No. 2 Tahun 2014.

Pengangkatan dan pemberhentian notaris tidak perlu menjadi kewenangan Organisasi Notaris sebab pada hakikatnya salah satu karakteristik notaris sebagai pejabat umum ialah diangkat dan diberhentikan oleh pemerintah. Kurang tepat apabila kewenangan tersebut dilimpahkan kepada Organisasi Notaris yang notabene bukan organ pemerintah karena akan menghilangkan karakteristik yang melekat pada notaris sebagai pejabat umum. Sesuai dengan ketentuan Pasal 2 UU No. 30 Tahun 2004, kewenangan untuk mengangkat dan memberhentikan notaris berada di tangan pemerintah, dalam hal ini Menteri Hukum dan Hak Asasi Manusia. Sedangkan keberadaan Organisasi Notaris secara umum hanya bertujuan untuk meningkatkan kualitas profesi notaris melalui kegiatan pendidikan dan pelatihan, pertemuan ilmiah, ceramah, seminar, dan sebagainya, baik di tingkat pusat, wilayah, maupun daerah.

\section{Rekomendasi}

Peraturan Menteri yang mengatur tentang syarat dan tata cara pengangkatan notaris perlu disempurnakan dan diselaraskan untuk menjamin kepastian hukum dan memberikan perlindungan hukum bagi para calon notaris.

\section{DAFTAR PUSTAKA}

\section{Peraturan Perundangan-undangan:}

Undang-Undang Republik Indonesia Nomor 30 Tahun 2004 tentang Jabatan Notaris.

Undang-Undang Republik Indonesia Nomor 2 Tahun 2014 tentang Perubahan Atas Undang-Undang Republik Indonesia Nomor 30 Tahun 2004 tentang Jabatan Notaris.

Peraturan Menteri Hukum dan Hak Asasi Manusia Republik Indonesia Nomor 62 Tahun 2016 tentang Perubahan Atas Peraturan Menteri Hukum dan Hak Asasi Manusia Republik Indonesia Nomor 25 Tahun 2014 tentang Syarat dan Tata Cara Pengangkatan, Perpindahan, Pemberhentian dan Perpanjangan Masa Jabatan Notaris.

\section{Buku:}

A.A. Andi Prajitno. (2015). Pengetahuan Praktis tentang Apa dan Siapa Notaris di Indonesia. Surabaya: Perwira Media Nusantara.

G.H.S. Lumban Tobing. (1982). Peraturan Jabatan Notaris. Jakarta: Erlangga.

Habib Adjie. (2009). Hukum Notaris Indonesia (Tafsir Tematik Terhadap UU No. 30 Tahun 2004 tentang Jabatan Notaris). Bandung: Refika Aditama.

Peter Mahmud Marzuki. (2011). Penelitian Hukum. Jakarta: Kencana. 